University of Nebraska - Lincoln

DigitalCommons@University of Nebraska - Lincoln

Agronomy \& Horticulture -- Faculty Publications

Agronomy and Horticulture Department

1997

\title{
Chlorophyll Meter and Stalk Nitrate Techniques as Complementary Indices for Residual Nitrogen
}

Gary E. Varvel

University of Nebraska-Lincoln, gevarvel@windstream.net

James S. Schepers

University of Nebraska-Lincoln, james.schepers@gmail.com

Dennis D. Francis

University of Nebraska-Lincoln, dfrancis1@unl.edu

Follow this and additional works at: https://digitalcommons.unl.edu/agronomyfacpub

Part of the Plant Sciences Commons

Varvel, Gary E.; Schepers, James S.; and Francis, Dennis D., "Chlorophyll Meter and Stalk Nitrate Techniques as Complementary Indices for Residual Nitrogen" (1997). Agronomy \& Horticulture -- Faculty Publications. 332.

https://digitalcommons.unl.edu/agronomyfacpub/332

This Article is brought to you for free and open access by the Agronomy and Horticulture Department at DigitalCommons@University of Nebraska - Lincoln. It has been accepted for inclusion in Agronomy \& Horticulture -Faculty Publications by an authorized administrator of DigitalCommons@University of Nebraska - Lincoln. 


\section{Chlorophyll Meter and Stalk Nitrate Techniques as Complementary Indices for Residual Nitrogen}

Gary E. Varvel, James S. Schepers, and Dennis D. Francis

\section{Research Question}

\section{Literature Summary}

\author{
Study Description
}

\section{Applied Questions}

Improved $\mathrm{N}$ management techniques are needed to reduce nitrate- $\mathrm{N}$ contamination of groundwater while maintaining yields. These techniques are especially critical for crops such as irrigated corn, which require large $\mathrm{N}$ fertilizer inputs. Our objective was to determine if some of these techniques could be used to guide and improve future soil sampling strategies that would result in improved $\mathrm{N}$ fertilizer recommendations and reduced adverse environmental effects. The techniques included using chlorophyll meters to monitor crop $\mathrm{N}$ status during the growing season and collecting end-of-season stalk samples for nitrate- $\mathrm{N}$ determinations.

Several studies have shown that chlorophyll meters can effectively monitor the $\mathrm{N}$ status of corn throughout the growing season. Others have shown that the end-of-season stalk nitrate- $\mathrm{N}$ test may provide some indication of excess crop $\mathrm{N}$ at maturity. Little research is available that compares in-season and end-of-season measures of $\mathrm{N}$ availability.

An irrigated monoculture corn and soybean-corn cropping systems study with cropping system as the first split, com hybrid as the second split, and $\mathrm{N}$ fertilizer rate as the final split in four replications was used. Four commercially available Pioneer brand corn hybrids $(3162,3379,3394$, and 3417) were evaluated in both cropping systems. Nitrogen fertilizer as ammonium nitrate was broadcast at rates of $0,45,90,135$, and $180 \mathrm{lb} N /$ acre in 1991 and 1992 and 0,56 , 112,168 , and $224 \mathrm{lb} \mathrm{N} /$ acre in the 1993 and 1994 growing seasons.

Did chlorophyll meter readings taken throughout the growing season reflect the $\mathbf{N}$ status of corn?

Chlorophyll meters proved to be an effective way to discern whether sufficient $\mathrm{N}$ was available to corn throughout the growing season in both cropping systems. It did not indicate how much additional $\mathrm{N}$ was needed in deficient plants when the readings were low or how much excess $\mathrm{N}$ was available once the readings had reached a maximum. Chlorophyll meter readings increased to a plateau at the optimum $\mathrm{N}$ fertilizer rate and then did not increase with additional $\mathrm{N}$ fertilizer applications (Fig. 1a).

Do stalk nitrate- $\mathrm{N}$ concentrations reflect the $\mathrm{N}$ status of irrigated corn at the end of the growing season?

End-of-season stalk nitrate- $\mathrm{N}$ concentrations reached established thresholds $(-2000 \mathrm{ppm})$ at the same $\mathrm{N}$ fertilizer rate where maximum yield and chlorophyll meter readings were obtained and then continued to increase with application of additional $\mathrm{N}$ (Fig. 1b). Nitrogen deficient plants had stalk nitrate-N values below the threshold level.

Can the chlorophyll meter and end-of-season stalk nitrate-N techniques be used to improve residual $\mathbf{N}$ sampling strategies?

Our data indicated when chlorophyll meters and the end-of-season stalk nitrate$\mathrm{N}$ test are used in conjunction they provide additional criteria to help partition

Full scientific article from which this summary was written begins on page 147 of this issue. 


\section{Recommendation}

and separate fields for future sampling into areas with potentially different levels of residual soil $\mathrm{N}$. Improved sampling strategies will result in better site-specific $\mathbf{N}$ fertilizer recommendations and decrease environmental risk because the amount of nitrate- $\mathrm{N}$ available for leaching is reduced. For example, in Fig. 1, residual soil $\mathrm{N}$ levels started to increase at the same fertilizer rates that yield and chlorophyll meter readings reached a maximum and stalk nitrate- $N$ concentrations exceeded $-2000 \mathrm{ppm}$, indicating excess nitrate- $\mathrm{N}$ was available for leaching.

Chlorophyll meters and stalk nitrate- $\mathrm{N}$ measurements can be used concurrently to determine areas where residual soil $\mathrm{N}$ levels may be either excessive or potentially $\mathrm{N}$ deficient. This research provides data that can be used to improve future $\mathrm{N}$ recommendations for irrigated corn because it identifies additional criteria to help partition and separate fields into areas with potentially different levels of residual soil $\mathrm{N}$. Use of both methods can improve $\mathrm{N}$ fertilizer recommendations and concurrently reduce environmental risk by reducing the amount of nitrate- $\mathrm{N}$ available for leaching.

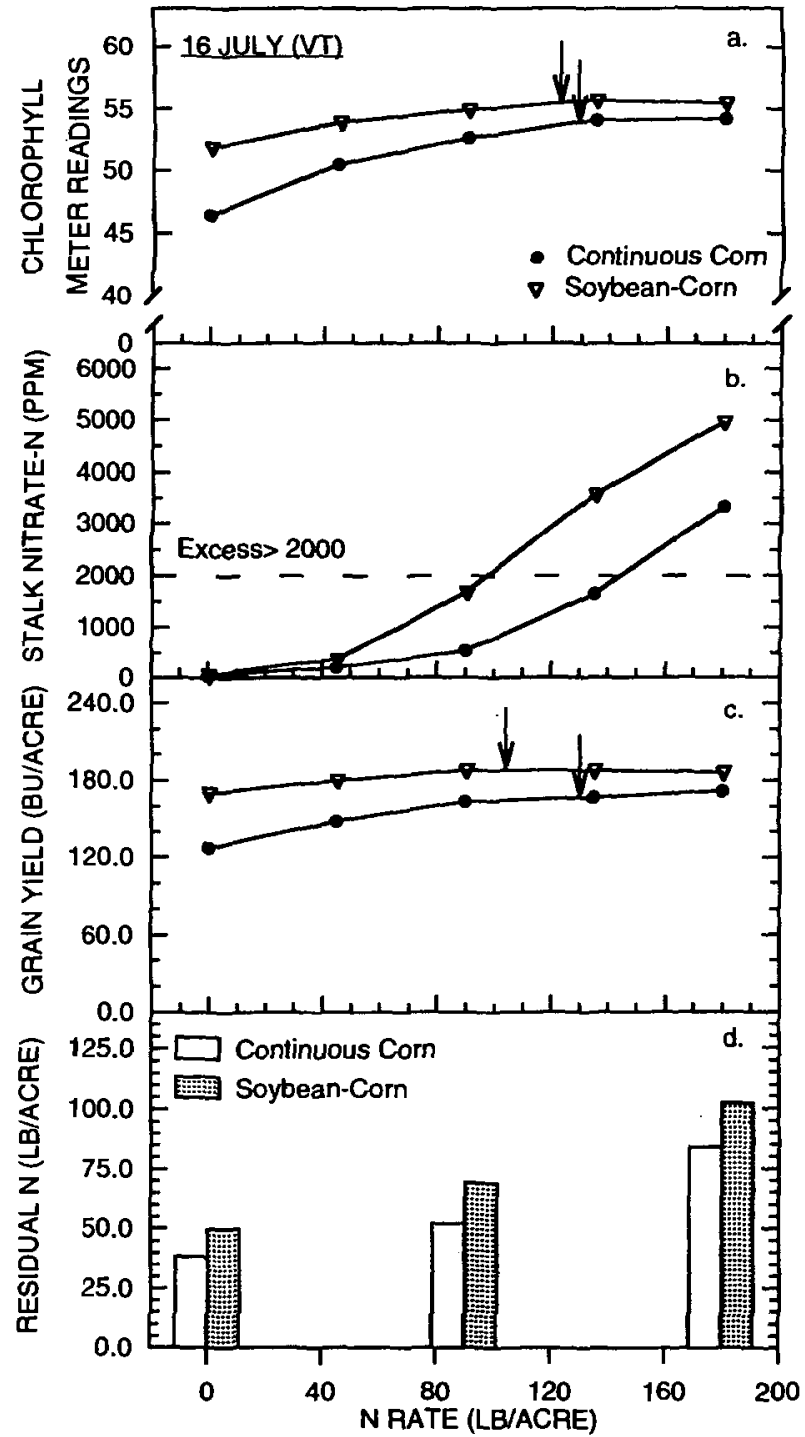

Fig. 1. Chlorophyll meter readings at VT growth stage (a), stalk nitrate- $N$ concentrations (b), grain yield (c), and residual soil $N$ (d) as affected by $\boldsymbol{N}$ fertilizer in continuous corn and soybean-corn rotations. Arrows denote $\mathrm{N}$ fertilizer rate at which maximum values were obtained. 


\title{
Chlorophyll Meter and Stalk Nitrate Techniques as Complementary Indices for Residual Nitrogen
}

\author{
Gary E. Varvel,* James S. Schepers, and Dennis D. Francis
}

\begin{abstract}
Improved $\mathbf{N}$ management techniques are needed to prevent excess $\mathbf{N}$ applications while maintaining yields. Environmentally, development of these improved techniques has become critical for crops such as irrigated corn (Zea mays $\mathrm{L}$.), which require large $\mathbf{N}$ fertilizer inputs to maximize yield. Our objective was to determine if some current $\mathbf{N}$ management techniques could be used to guide and improve future soil sampling strategies that would result in improved $\mathbf{N}$ fertilizer recommendations and reduced adverse environmental effects. Chlorophyll meter readings and end-of-season stalk nitrate-N concentrations were taken from an irrigated corn study at Sheiton, NE, from 1992 through 1994. Residual soil N samples were collected to a depth of 5 ft after the 1992 and 1993 growing seasons. This study included continuous corn and soybean [Glycine max (L.) Merr.]- corn rotations with four corn hybrids and five $\mathbf{N}$ fertilizer rates. Chlorophyll meter readings taken at several growth stages reached a maximum at sufficient $N$ levels for maximum yield and then plateaued. Similarly, end-of-season stalk nitrate- $N$ concentrations exceeded established thresholds ( $-2000 \mathrm{ppm})$ above the $\mathbf{N}$ fertilizer rate where maximum yields were obtained in both cropping systems. Together, these techniques provided additional criteria to help partition and separate fields into areas with potentially different levels of residual soil $\mathbf{N}$. This information can then be used to guide soil sampling and to develop or improve site specific $\mathbf{N}$ fertilizer recommendations which should decrease environmental risk by reducing the amount of nitrate- $\mathrm{N}$ available for leaching.
\end{abstract}

$\mathrm{E}$ NVIRONMENTAL CONCERNS have accentuated the need for improved $\mathrm{N}$ management techniques to reduce the potential for nitrate- $\mathrm{N}$ contamination of groundwater while maintaining yields for the producer. These concerns are greatest for crops that require large $\mathrm{N}$ fertilizer inputs to maximize yield. Among these types of crops, corn is of major concern because of the large number of acres grown in the USA. and its large $N$ requirement. It is especially a concern in those areas where irrigated monoculture corn is the dominant cropping system because the combination of large $\mathrm{N}$ fertilizer applications and irrigation greatly increases the potential for nitrate leaching.

Several measures of $\mathrm{N}$ availability are being developed for use in an attempt to both predict $\mathrm{N}$ fertilizer need (Piekielek and Fox, 1992) and determine in-season crop $\mathrm{N}$ status (Wood et al., 1992; Blackmer and Schepers, 1994, 1995). These methods have met with varying degrees of success in their ability to predict $\mathrm{N}$ needs or measure in-season $\mathrm{N}$ status of the crop.

USDA-ARS and Dep. of Agronomy, Univ. of Nebraska, Lincoln, NE 68583. Joint contribution of USDA-ARS and the Nebraska Agric. Res. Div., J. Series no. 11283. Received 11 Sept. 1995. *Corresponding author (gvarvel@unlinfo.unl.edu).

Published in J. Prod. Agric. 10:147-151 (1997).
One tool for monitoring in-season $\mathrm{N}$ status, the chlorophyll meter, has been used in several different ways since coming on the market in the late 1980s. Researchers and others have used them in many different situations and on a number of different crops, generally to evaluate, determine, or measure $\mathrm{N}$ status. This technique has been successful because chlorophyll content has been shown to be highly correlated with leaf $\mathrm{N}$ concentration (Wolfe et al., 1988; Lohry, 1989; Schepers et al., 1992). The meter measures light transmittance through a leaf at $\approx 650 \mathrm{~nm}$, which lies between the primary wavelengths (i.e., 645 and $663 \mathrm{~nm}$ ) associated with chlorophyll activity in vitro.

A method that may provide an indication of soil $\mathrm{N}$ status at crop maturity is the end-of-season stalk nitrate- $\mathrm{N}$ test as proposed by Binford et al. (1990). Their results from Iowa field studies indicated that corn grown with excessive amounts of available $\mathrm{N}$ tend to accumulate nitrate- $\mathrm{N}$ in the lower portion of the stalk. The more nitrate- $N$ remaining above a threshold level in the lower stalk at maturity, the more $\mathrm{N}$ was in excess during the growing season.

Concern about nitrate- $N$ contamination of groundwater in the Platte River Valley of Nebraska and other areas of the USA prompted this and several related studies. The overall objective of these studies is to investigate how best management practices can be used to reduce nitrate- $\mathrm{N}$ contamination of groundwater to acceptable levels. In addition, specific aspects or components are designed to investigate and compare effects of monoculture corn and soybean-corn systems on $\mathrm{N}$ use and efficiency. The specific objective of this study was to determine if chlorophyll meters and the end-ofseason stalk nitrate- $\mathrm{N}$ test could be used as tools to guide and improve future soil sampling strategies that would result in improved $\mathrm{N}$ fertilizer recommendations and reduced adverse environmental effects. Data from this study will be used to provide a link between in-season and end-of-season measures of $\mathrm{N}$ availability.

\section{MATERIALS AND METHODS}

A study comparing irrigated monoculture corn and soybean-com cropping systems was initiated in 1991. The study was conducted on a site in the Platte Valley near Shelton, NE, on a Hord silt loam (fine-silty, mixed, mesic, Pachic Haplustoll).

The site had been in monoculture irrigated corn production for at least 10 years prior to the study. Corn stalks from the previous growing season were initially shredded and the entire area was disked twice before planting. Subsequently, corn stalks from both cropping systems were shredded and the entire area, including that in soybean, was disked twice before planting.

Abbreviations: V8, eight-leaf corn growth stage; VT, tasseling growth stage of corn; R2, blister growth stage of com. 
A split-split-split plot design with cropping system as the first split, corn hybrid as the second split, and $\mathrm{N}$ fertilizer rate as the final split in four replications was used. All components of the monoculture corn and soybean-com systems have appeared each year starting with the 1991 growing season. Four commercially available Pioneer brand corm hybrids $(3162,3379,3394$, and 3417$)$ were evaluated in both cropping systems. Corn was planted between late April and mid May in eight-row (36-in. spacing) by 50-ft long plots at approximately 29000 seeds/acre, and soybean was planted in early to mid May.

Nitrogen fertilizer as ammonium nitrate was broadcast on the soil surface and immediately incorporated with a $\mathbf{0 . 2 5}$ in. irrigation in early June. Five $\mathrm{N}$ fertilizer rates were used on both crops. Rates of $0,45,90,135$, and $180 \mathrm{lb}$ N/acre were used in 1991 and 1992 and $0,56,112,168$, and $224 \mathrm{lb}$ N/acre for the 1993 and 1994 growing seasons. Nitrogen fertilizer rates were increased after the 1991 and 1992 growing seasons when it appeared they were not sufficient for maximum yields. Irrigation was provided as needed with a linear drive sprinkler system. Nitrate- $N$ concentrations in the irrigation water averaged $-30 \mathrm{ppm}$ which resulted in $\sim 7$ lb N/acre being applied with each 1 in. Total amounts of $N$ from the irrigation water differed from year to year (ranging from $\sim 10$ to $50 \mathrm{lb} \mathrm{N} /$ acre), but all plots received the same amount within a given year.

In-season N status was monitored weekly using SPAD 502 chlorophyll meters (Peterson et al., 1993) starting at the V8 (eighth leaf collar fully exposed) growth stage (Ritchie et al., 1986) and continuing through R2 (blister). Chlorophyll meter readings were taken from the newest fully expanded leaf that has a collar exposed until VT (tasseling). After tassel stage, the ear leaf was measured. All measurements were taken on 30 randomly selected plants within each plot.

Stalk nitrate- $\mathrm{N}$ concentrations were determined on lower stalk samples taken at physiological maturity (Blackmer and Mallarino, 1994). Six- to eight-in. segments were taken from the bottom of 10 stalks when samples were being collected for total dry matter yield determinations. The stalk samples were then chopped, dried, and ground before being analyzed for nitrate-N. Grain yield was determined with a plot combine by harvesting three of the center rows for the entire length of each plot. Yield data were adjusted to $15.5 \%$ water content.

Soil samples were taken to a depth of $5 \mathrm{ft}$ in the spring of 1993 from the 0,90 , and $180 \mathrm{lb} \mathrm{N} / \mathrm{acre}$ and in the spring of 1994 from the 0,112 , and $224 \mathrm{lb} \mathrm{N} /$ acre treatments to measure the amount of residual N left after the 1992 and 1993 growing seasons, respectively. Soil samples were not taken in the spring of 1995 because of extremely wet conditions. All soil samples were dried, ground, and analyzed for nitrate-N (Keeney and Nelson, 1982). Soil samples were not analyzed for ammonium- $\mathrm{N}$ because experience had shown ammonium- $\mathrm{N}$ levels did not vary between samples at any time during the growing season.

Chlorophyll meter readings and stalk samples were collected starting in 1992. Data from the study were analyzed by year. All statistical analyses were performed using the Statistical Analyses System (SAS Institute, 1992). The GLM procedure in SAS was used to determine at what N fertilizer rate maximum chlorophyll meter and grain yield values were obtained for data shown in Figs. 1, 2, and 3.

\section{RESULTS}

Rotation and $\mathrm{N}$ fertilizer rate significantly affected chlorophyll meter readings at both V8 and VT growth stages in all $3 \mathrm{yr}$, while hybrid effects tended to be significant at

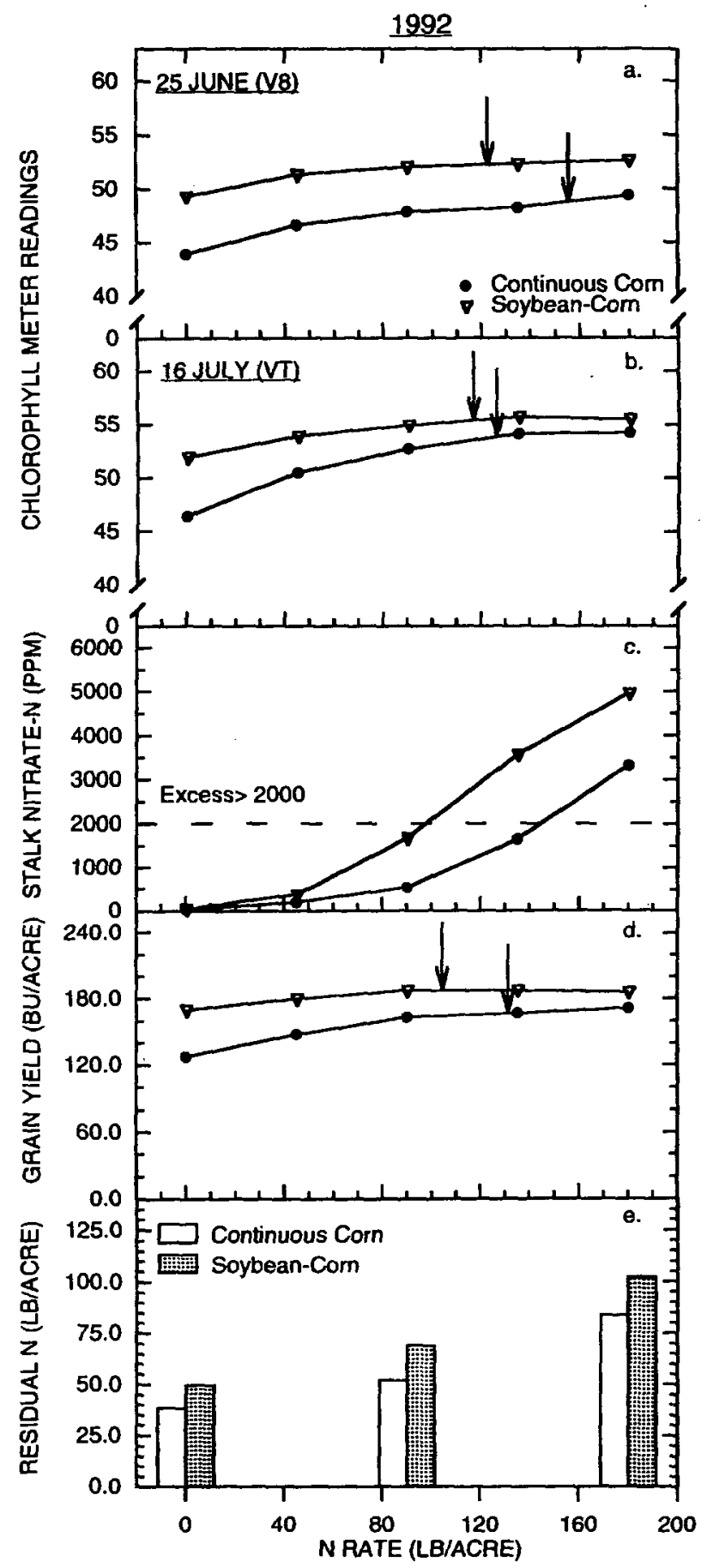

Fig. 1. Chlorophyll meter readings at V8 (a) and VT (b) growth stages, stalk nitrate- $N$ concentrations (c), grain yield (d), and residual soil $N$ to a depth of $5 \mathrm{ft}$ in the spring following the 1992 growing season (e) as affected by $\mathbf{N}$ fertilizer for irrigated corv in continuous corn and soybean-com rotations in 1992 at Shelton, NE. Arrows denote $N$ fertilizer rate at which maximum values were obtained. 
only the later sampling date (Tables 1 through 3). Results are only shown for these two growth stages because they provide information about the $\mathrm{N}$ status of the corn relatively early in the growing season and then again at midseason. Results for readings taken at the other sampling times in all 3 yr showed similar effects and will not be presented. In 1994, significant differences in chlorophyll meter readings were obtained between hybrids at the early sampling date.

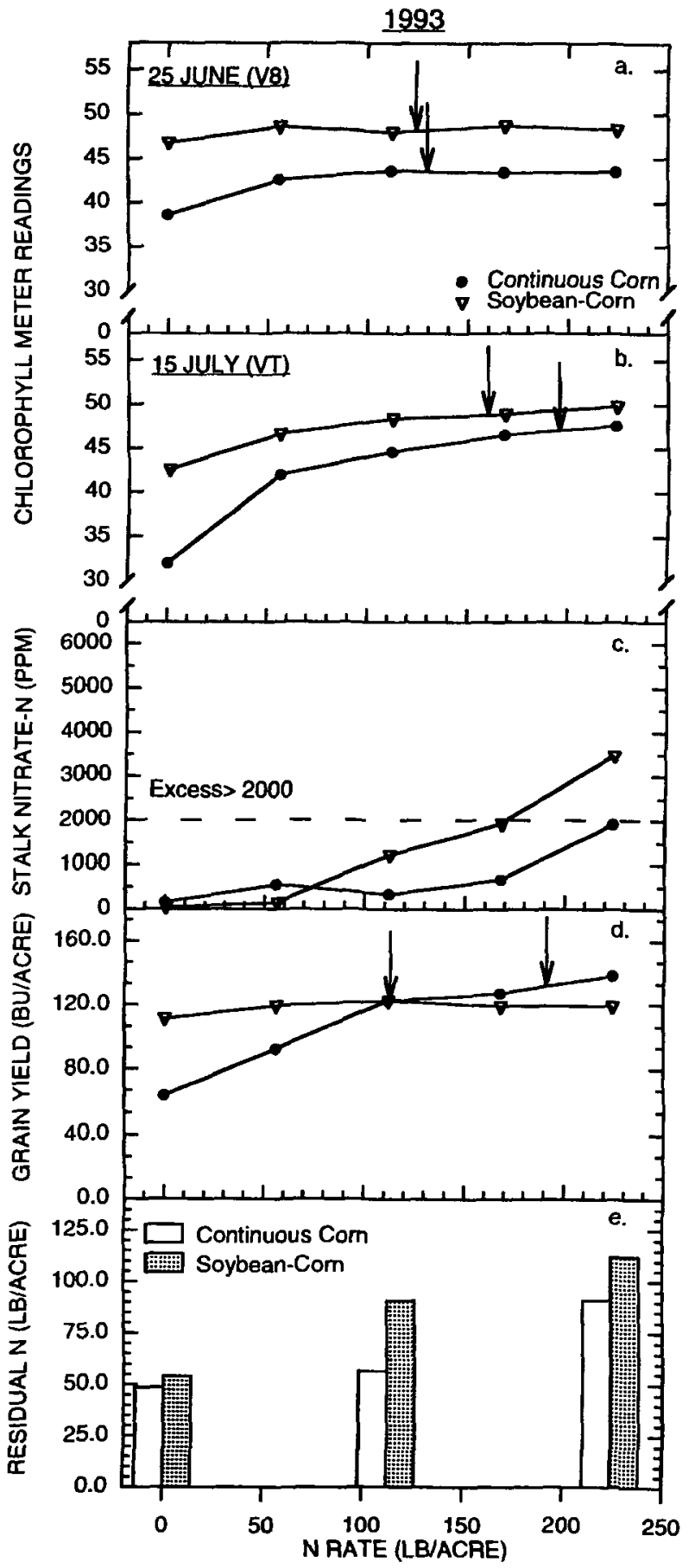

Fig. 2. Chlorophyll meter readings at V8 (a) and VT (b) growth stages, stalk nitrate- $\mathrm{N}$ concentrations (c), grain yield (d), and residual soil $\mathrm{N}$ to a depth of $5 \mathrm{ft}$ in the spring following the 1993 growing season (e) as affected by $\mathbf{N}$ fertilizer for irrigated corn in continuous corn and soybean-corn rotations in 1993 at Shelton, NE. Arrows denote $\mathbf{N}$ fertilizer rate at which maximum values were obtained.
Although significant, these differences between hybrids were not consistent between early and midseason sampling dates. For example, chlorophyll meter readings were greatest for 3162 at V8 and for 3379 at VT in 1994. In contrast, rotation and $\mathrm{N}$ fertilizer rate effects were similar in all $3 \mathrm{yr}$. Chlorophyll meter readings from corn in rotation were consistently greater than from those in monoculture corn. Likewise, meter readings tended to start low and then increase with $\mathrm{N}$ fertilizer rate to a plateau in all $3 \mathrm{yr}$.

In all $3 \mathrm{yr}$, a significant rotation $\times \mathrm{N}$ rate interaction for all but the early sampling date in 1992 was obtained (Tables 1 through 3). Results shown in Figs. 1, 2, and 3(a, b) for both sampling dates each year demonstrate this significant interaction. This difference resulted from chlorophyll meter readings always being much less in plots without $\mathrm{N}$ fertilizer for corn in monoculture than for corn in rotation. This presumably reflected the contribution of $\mathrm{N}$ from soybean in the soybean-corn rotation.

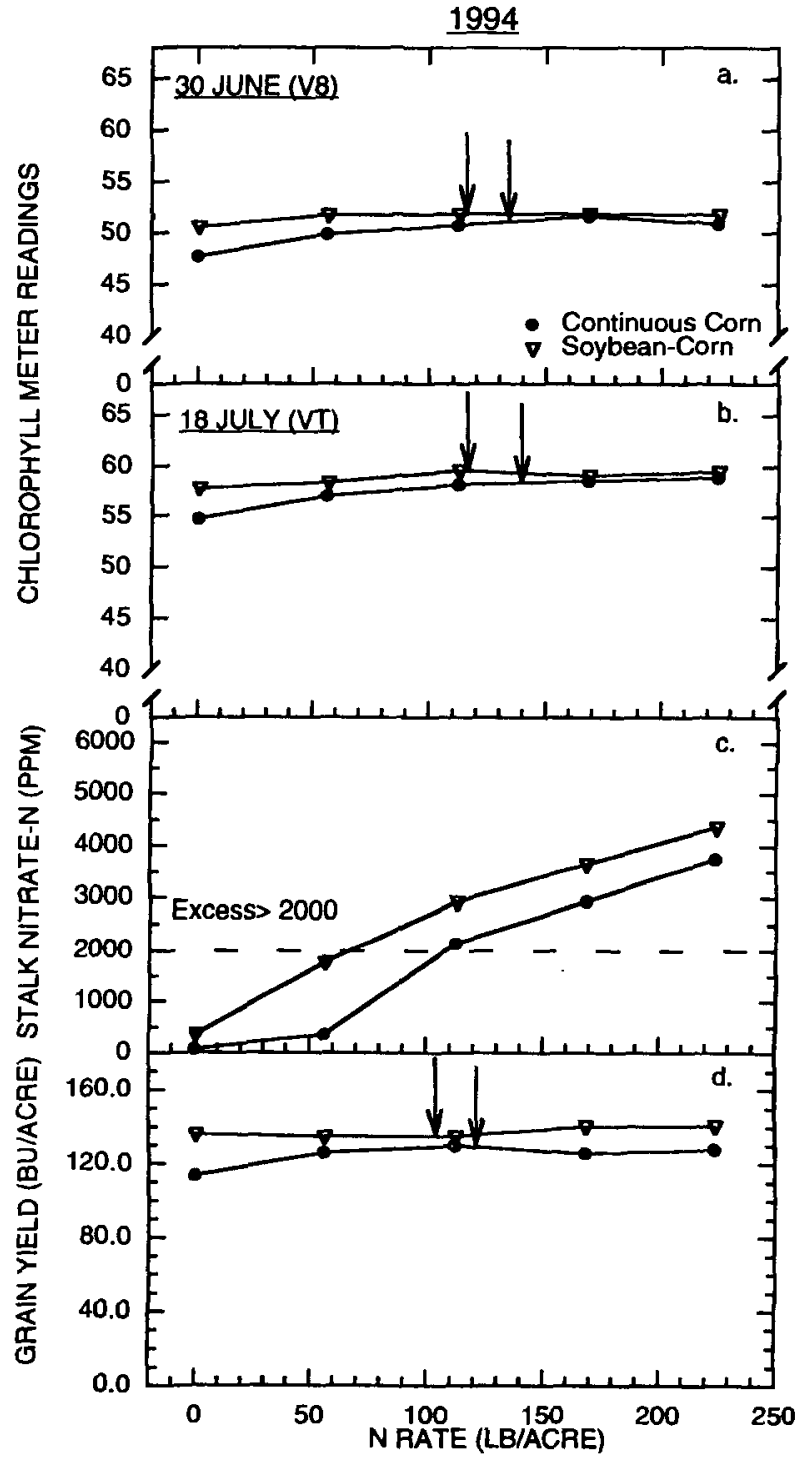

Fig. 3. Chlorophyll meter readings at approximately V8 (a) and VT (b) growth stages, stalk nitrate- $\mathbf{N}$ concentrations (c), and grain yield (d) as affected by $\mathbf{N}$ fertilizer for irrigated corn in continuous corn and soybean-corn rotations in 1994 at Shelton, NE. Arrows denote $\mathbf{N}$ fertilizer rate at which maximum values were obtained. 
Table 1. Mean squares and significance of rotation, hybrid, and $\mathrm{N}$ rate treatment effects for chlorophyll meter readings, stalk nitrate- $N$, and corn grain yield in 1992 at Shelton, NE.

\begin{tabular}{|c|c|c|c|c|c|}
\hline \multirow[b]{2}{*}{ Source } & \multirow[b]{2}{*}{ df } & \multicolumn{2}{|c|}{ Chlorophyll meter readings } & \multirow{2}{*}{$\begin{array}{c}\text { Stalk } \\
\text { Nitrate-N }\end{array}$} & \multirow{2}{*}{$\begin{array}{l}\text { Grain } \\
\text { yield }\end{array}$} \\
\hline & & V8t & VT & & \\
\hline & & \multicolumn{4}{|c|}{ Mean squares } \\
\hline Block & 3 & 89.0 & 198.6 & 3.5 & 4.1 \\
\hline Rotation(R) & 1 & $739.2^{* *}$ & $314.2^{*}$ & $38.2^{* *}$ & $183.2^{* *}$ \\
\hline Error a & 3 & 1.8 & 26.0 & 1.0 & 1.1 \\
\hline Hybrid(H) & 3 & 1.0 & $45.3 * *$ & 2.4 & 7.3 \\
\hline $\mathbf{R} \times \mathbf{H}$ & 3 & 4.0 & 1.6 & 0.3 & 8.4 \\
\hline Error b & 18 & 9.9 & 6.7 & 0.9 & 3.6 \\
\hline $\mathrm{N} \operatorname{rate}(\mathrm{N})$ & 4 & $91.5^{* *}$ & $186.0^{* *}$ & $95.5^{* *}$ & $35.3^{* *}$ \\
\hline $\mathbf{R} \times \mathbf{N}$ & 4 & 5.7 & $22.7 * *$ & $5.8^{* *}$ & $6.5^{* *}$ \\
\hline$H \times N$ & 12 & 3.7 & 2.1 & 1.2 & 1.3 \\
\hline $\mathrm{R} \times \mathrm{H} \times \mathrm{N}$ & 12 & 4.3 & 2.4 & 1.5 & 1.0 \\
\hline Error c & 96 & 6.2 & 3.0 & 1.0 & 0.6 \\
\hline$C V(\%)$ & & 5.0 & 3.3 & 60.3 & 7.4 \\
\hline
\end{tabular}

*** Significant at the 0.05 and 0.01 probability levels.

$\dagger$ Com plant growth stages V8 (8 leaf) and VT (tasseling).

Table 2. Mean squares and significance of rotation, hybrid, and $\mathbf{N}$ rate treatment effects for chlorophyll meter readings, stalk nitrate- $N$, and corn grain yield in 1993 at Shelton, NE.

\begin{tabular}{|c|c|c|c|c|c|}
\hline \multirow[b]{2}{*}{ Source } & \multirow[b]{2}{*}{ df } & \multicolumn{2}{|c|}{ Chlorophyll meter readings } & \multirow{2}{*}{$\begin{array}{c}\text { Stalk } \\
\text { Nitrate-N }\end{array}$} & \multirow{2}{*}{$\begin{array}{l}\text { Grain } \\
\text { yield }\end{array}$} \\
\hline & & V8† & VT & & \\
\hline & & \multicolumn{4}{|c|}{ - Mean squares } \\
\hline Block & 3 & 312.3 & 83.2 & 2.9 & 4.0 \\
\hline Rotation(R) & 1 & $1317.3^{* *}$ & $895.4^{*}$ & 15.9 & $14.6^{*}$ \\
\hline Error a & 3 & 23.7 & 66.4 & 15.4 & 0.9 \\
\hline Hybrid(H) & 3 & 2.0 & $21.6^{*}$ & $3.6^{*}$ & $26.8^{* *}$ \\
\hline $\mathbf{R} \times \mathbf{H}$ & 3 & 1.8 & 2.2 & 0.1 & $18.2 * *$ \\
\hline Error b & 18 & 6.3 & 6.5 & 0.9 & 0.7 \\
\hline $\mathrm{N} \operatorname{rate}(\mathrm{N})$ & 4 & $63.6^{* *}$ & $666.2^{* *}$ & $34.0^{* *}$ & $36.0^{* *}$ \\
\hline $\mathbf{R} \times \mathbf{N}$ & 4 & $16.9^{* *}$ & $92.5 * *$ & $5.9 * *$ & $25.4^{* *}$ \\
\hline $\mathrm{H} \times \mathrm{N}$ & 12 & 1.2 & $7.4^{*}$ & 1.3 & $2.5^{* *}$ \\
\hline $\mathrm{R} \times \mathbf{H} \times \mathbf{N}$ & 12 & 1.7 & 1.2 & 0.9 & 0.6 \\
\hline Error c & 96 & 3.6 & 3.9 & 1.4 & 0.5 \\
\hline CV(\%) & & 4.2 & 4.4 & 113.8 & 9.6 \\
\hline
\end{tabular}

*,** Significant at the 0.05 and 0.01 probability levels

† Corn plant growth stages V8 (8 leaf) and VT (tasseling)

Rotation, hybrid, and $\mathrm{N}$ fertilizer effects on end-of-season stalk nitrate- $\mathrm{N}$ concentrations and grain yield are also shown in Tables 1, 2, and 3 for the 3 yr of the study. Rotation significantly affected stalk nitrate- $\mathrm{N}$ concentrations, except during 1993 and grain yield, except for 1994. Hybrid effects were significant for stalk nitrate-N concentrations in 1993 (Table 2) and grain yield in 1993 and 1994 (Tables 2 and 3). Nitrogen fertilizer rate significantly affected stalk nitrate- $\mathrm{N}$ concentrations and grain yield all $3 \mathrm{yr}$. Most of the inconsistencies in the rotation and hybrid effects were due to variability in 1993 and 1994 caused by severe wind storm damage in mid July of both years.

Significant interaction effects for stalk nitrate- $N$ concentrations and grain yield were similar to those obtained for chlorophyll meter readings. The rotation $\times \mathrm{N}$ fertilizer rate interaction significantly affected stalk nitrate- $\mathrm{N}$ concentrations in 1992 and 1993 and grain yield throughout the study (Tables 1, 2, and 3). A significant hybrid $\times \mathrm{N}$ fertilizer rate effect was also shown for stalk nitrate-N concentrations in 1994 (Table 3) and grain yield in 1993 (Table 2). As noted for the main effects, many of the interactions were probably significant because of wind storm damage in 1993 and 1994.

Residual soil N results for the 1992 and 1993 growing seasons are shown in Figs. le and $2 e$. The amount of resid-
Table 3. Mean squares and significance of rotation, hybrid, and $\mathrm{N}$ rate treatment effects for chlorophyll meter readings, stalk nitrate-N, and corn grain yield in 1994 at Shelton, NE.

\begin{tabular}{|c|c|c|c|c|c|}
\hline \multirow[b]{2}{*}{ Source } & \multirow[b]{2}{*}{ df } & \multicolumn{2}{|c|}{ Chlorophyll meter readings } & \multirow{2}{*}{$\begin{array}{c}\text { Stalk } \\
\text { Nitrate-N }\end{array}$} & \multirow{2}{*}{$\begin{array}{l}\text { Grain } \\
\text { yield }\end{array}$} \\
\hline & & V8† & VT & & \\
\hline & & \multicolumn{4}{|c|}{ - Mean squares $\longrightarrow$} \\
\hline Block & 3 & 22.4 & 2.3 & 1.2 & 12.5 \\
\hline Rotation(R) & 1 & $77.0^{* *}$ & $76.7^{* *}$ & $23.3^{*}$ & 25.3 \\
\hline Error a & 3 & 2.0 & 1.5 & 2.4 & 22.0 \\
\hline Hybrid(H) & 3 & $32.0^{* *}$ & $6.0^{*}$ & 0.5 & $50.8^{* *}$ \\
\hline $\mathbf{R} \times \mathbf{H}$ & 3 & 2.7 & 1.1 & 0.3 & 1.8 \\
\hline Error b & 18 & 2.8 & 1.6 & 1.1 & 2.5 \\
\hline $\mathrm{N}$ rate( $(\mathrm{N})$ & 4 & $33.1^{* *}$ & $48.2^{* *}$ & $80.1^{* *}$ & $1.7^{*}$ \\
\hline $\mathrm{R} \times \mathrm{N}$ & 4 & $8.8^{* *}$ & $8.8^{* *}$ & 1.4 & $1.3^{*}$ \\
\hline$H \times \mathbf{N}$ & 12 & 1.5 & 1.5 & $1.3^{*}$ & 0.8 \\
\hline $\mathrm{R} \times \mathrm{H} \times \mathrm{N}$ & 12 & 1.8 & 0.9 & 0.5 & 0.5 \\
\hline Error c & 96 & 1.8 & 1.2 & 0.7 & 0.5 \\
\hline CV(\%) & & 2.6 & 1.9 & 36.6 & 8.9 \\
\hline
\end{tabular}

*** Significant at the 0.05 and 0.01 probability levels.

$\dagger$ Com plant growth stages V8 (8 leaf) and VT (tasseling).

ual $\mathrm{N}$ in both cropping systems followed similar trends as those for stalk nitrate- $\mathrm{N}$ and grain yield in Figs. 1 and 2 (c, d). Residual $\mathrm{N}$ amounts in both cropping systems for treatments that received no fertilizer $\mathrm{N}$ was small $(50 \mathrm{lb} / \mathrm{acre}$ or less in the top $5 \mathrm{ft}$ ) and essentially as low as $\mathrm{N}$ levels ever get in most soils in the Platte Valley. Residual $\mathrm{N}$ appeared to remain low until fertilizer $\mathrm{N}$ rates were sufficient for maximum yields, and then increased. Residual $\mathrm{N}$ amounts were greater following soybean at all $\mathrm{N}$ rates during both years, which also followed similar trends shown in Figs. le and $2 \mathrm{e}$.

\section{DISCUSSION}

The chlorophyll meter and stalk nitrate- $\mathrm{N}$ results are similar to those obtained and reported by several researchers (Binford et al., 1992; Piekielek and Fox, 1992; Wood et al., 1992; Blackmer and Schepers, 1994, 1995). Separately they provide information that improves our understanding of $\mathrm{N}$ dynamics and management.

Chlorophyll meter readings demonstrate that when the values reach a plateau at any of the growth stages measured from V8 to VT, $\mathrm{N}$ fertilizer is sufficient for maximum yield. If $\mathrm{N}$ levels ranging from deficient to excessive exist in a corn field, chlorophyll meter readings can be used to identify those areas where $\mathrm{N}$ will be insufficient for maximum yield. However, since chlorophyll meter readings reach a plateau at sufficient $\mathrm{N}$ levels and do not increase above that, it is not possible to distinguish areas in the field which contain an adequate amount of $\mathrm{N}$ from those areas where excessive $\mathrm{N}$ levels exist.

In contrast, end-of-season stalk nitrate- $\mathrm{N}$ concentrations increase with $\mathrm{N}$ fertilizer applications and will continue to increase above the point where the amount of $\mathrm{N}$ available to the plant becomes excessive to plant needs and remains readily available for loss by leaching.

Together, these results are shown in Figs. 1, 2, and 3 where chlorophyll meter readings, and end-of-season stalk nitrate- $\mathrm{N}$ concentrations for each year are plotted on the same graph with grain yield for the five $\mathrm{N}$ fertilizer rates. End-of-season stalk nitrate- $\mathrm{N}$ concentrations approach and then exceed the threshold concentration of $2000 \mathrm{ppm}$ at or near the $\mathbf{N}$ fertilizer rate where maximum chlorophyll meter readings and grain yield were obtained in both cropping sys- 
tems during all 3 yr (maximum values in each cropping system for chlorophyll meter readings and grain yields are identified by arrows). Residual soil $\mathrm{N}$ levels also support these results as the amount of $N$ in the soil remained low at $\mathrm{N}$ fertilizer rates sufficient or below that needed for maximum yields, but then increased when additional fertilizer $\mathrm{N}$ was applied (Figs le and 2e). The results are extremely consistent, except during 1993 when as noted earlier in the results section, major wind damage occurred. Even given this problem, if results from the 15 July date $(10 \mathrm{~d}$ after the wind storm) are used (Fig. 2b), maximum values occurred at similar $\mathrm{N}$ fertilizer rates as those for grain yield (Fig. 2), and given these conditions they agree well with stalk nitrate-N concentrations.

As discussed above, both chlorophyll meter readings and stalk nitrate- $\mathrm{N}$ concentrations can be used as indicators of in-season and end-of-season $\mathrm{N}$ availability. Our research also indicates they can be used to improve future $\mathrm{N}$ fertilizer recommendations. These tools give us the ability to move away from the concept of whole field sampling to the concept of site specific sampling (or where in the field to sample). Chlorophyll meter readings from various parts of a field (these locations can be selected based on management history, soil type, topography, etc.) throughout the growing season provide a temporal sequence of $\mathrm{N}$ status and availability. If a problem is detected with the chlorophyll meter early in the growing season, then more sampling is possible to verify whether the problem is short term or season long. Stalk nitrate- $\mathrm{N}$ values at the end of the growing season provide data at only that time. For example, if stalk nitrate-N values are low, you have no way to know whether that is a true measure of the actual $\mathrm{N}$ availability at that particular location or if the combination of $\mathrm{N}$ immobilization and mineralization, nitrate leaching, or denitrification has resulted in low stalk nitrate- $\mathrm{N}$ values at the end of the growing season. Stalk nitrate-N values, together with chlorophyll meter readings throughout the growing season, can provide this information.

When information from these two methods is used concurrently, our results demonstrate that they provide additional criteria to help partition and separate fields into areas with potentially different levels of residual soil $\mathrm{N}$. This information can then be used to improve soil sampling strategies and the resulting site specific $\mathrm{N}$ fertilizer recommendations. Improving both how much and where $\mathrm{N}$ fertilizer is applied using this information will reduce the amount of nitrate- $\mathrm{N}$ available for leaching.

\section{REFERENCES}

Binford, G. D., A. M. Blackmer, and N. M. El-Hout. 1990. Tissue test for excess nitrogen during corn production. Agron. J. 82:124-129.

Binford, G. D., A. M. Blackmer, and B. G. Meese. 1992. Optimal concentrations of nitrate in cornstalks at maturity. Agron. J. 84:881-887.

Blackmer, A. M., and A. P. Mallarino. 1994. Cornstalk testing to evaluate nitrogen management. Iowa State Univ. Coop. Ext. Serv. Agronomy $7-4$.

Blackmer, T. M., and J. S. Schepers. 1994. Techniques for monitoring crop nitrogen status in com. Commun. Soil Sci. Plant Anal. Vol. 25(9-10):1791-1800.

Blackmer, T. M., and J. S. Schepers. 1995. Use of a chlorophyll meter to monitor $\mathrm{N}$ status and schedule fertigation for com. J. Prod. Agric. 8:56-60.

Keeney, D. R., and D. W. Nelson. 1982. Nitrogen-inorganic forms. p. 643-698. In A. L. Page et al. (ed.) Methods of soil analysis. Part 2. 2nd ed. Agron. Monogr. 9. ASA and SSSA, Madison, WI.

Lohry, R. D. 1989. Effect of $N$ fertilizer rate and nitrapyrin on leaf chlorophyll, leaf $\mathrm{N}$ concentration, and yield of three irrigated maize hybrids in Nebraska. Ph.D. diss. Univ. of Nebraska, Lincoln (Diss. Abstr. 9013612).

Peterson, T. A., T. M. Blackmer, D. D. Francis, and J. S. Schepers. 1993. Using a chlorophyll meter to improve $N$ management. Univ. of Nebraska, Lincoln, Coop. Ext. Serv. Nebguide G93-1171A.

Piekielek, W. P., and R. H. Fox. 1992. Use of a chlorophyll meter to predict sidedress N requirements for maize. Agron. J. 84:59-65.

Ritchie, S. W., J. J. Hanway, and G. O. Benson. 1986. How a com plant develops. Iowa State Univ. Coop. Ext. Serv. Spec. Rep. 48.

Schepers, J. S., D. D. Francis, M. F. Vigil, and F. E. Below. 1992. Comparisons of corn leaf nitrogen and chlorophyll meter readings. Commun. Soil Sci. Plant Anal. 23:2173-2187.

SAS Institute. 1992. SAS/STAT user's guide. 4th ed. SAS Inst., Cary, NC.

Wolfe, D. W., D. W. Henderson, T. C. Hsiao, and A. Alvino. 1988. Interactive water and nitrogen effects on senescence of maize: II. Photosynthetic decline and longevity of individual leaves. Agron. J. 80:865-870.

Wood, C. W., D. W. Reeves, R. R. Duffield, and K. L. Edmisten. 1992. Field chlorophyll measurements for evaluation of corn nitrogen status. J. Plant Nutr. 15:487-500. 